\title{
The Empirical Research on Experience-typed Teaching Method in Philosophy Education Based on Mathematical Statistic Law
}

\author{
Yuxin Zheng \\ Chengdu University of Technology, School of geophysics, \\ Chengdu, China \\ zh_engyuxin@126.com
}

Keywords:decomposition model; treatment effect; experience-typed teaching method; comparison study; statistical analysis

\begin{abstract}
In order to research on students' taking ideological and political education and thinking morality courses in colleges and universities, the author took experiential education for research methods. The author randomly selected two classes from universities to have teaching control, with an experiential education and a traditional education. We make comparative analysis of the final tests before and after the results of the two classes, knowing that the obvious experiential teaching method will help enhance students' interest in the ideological and political education course.
\end{abstract}

\section{Introduction}

In the form of college education reform, the status and role of the ideological and political education in colleges and universities teaching also can not be ignored, but how to make correct thinking when carrying out a full teaching improve the students' ideological and political teaching interest? Therefore, the article will integrate experiential teaching into universities ideological and political education teaching[1-3]. This not only makes the students get excited of this course, and students can fully demonstrate and achieve while also realizing the overall improvement of themselves[4,5].

\section{Experiential pedagogy and research methods}

Experiential teaching attracted the attention of scholars in the era of the rise of the quality of education, but also brought a certain impact to the ideological and political education at home and abroad, so experiential teaching methods and ideas is worthy to explore.

Experiential teaching is synchronized with the content of the teaching, and teaching method is in a variety of ways a combination of creative design and layout and organization[6]. At the same time, together with the teacher, tips and guide, and so do the students who are the main part and actively use their brains, hands and actively participate in classroom activities, to participate in the experience, and to give their personal potential into full play in order to improve classroom efficiency and enhance education.

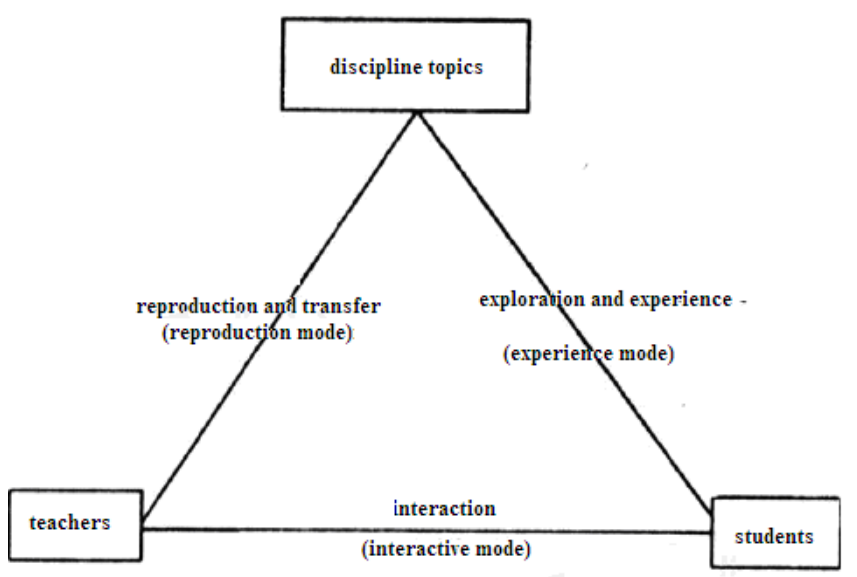

Figure 1. Experiential pedagogy model 
As can be seen from Figure 1 experiential pedagogy teaching model, experiential pedagogy focuses on the effective combination of the three: discipline topics, teachers and students. Interactive mode of interaction between teachers and students, for subject teachers between the representation and the role of the pass is a reproduction mode. Teachers teach their students through teaching disciplines theme. For academic topics with students is a way to explore and experience, and also is an experience mode. The three interact and promote each other, and it is the only way to achieve effective transfer of disciplines theme ideas as well as efficient teaching of teachers and students[7].

From Table 1 showing the traditional teaching and experiential teaching's difference between "understanding", it can be seen traditional teaching, which only concerned to explain and disseminate knowledge, but there is no the experiential teaching to make students actively use their brains to think and to form their own knowledge and insights[8].

TABLE I. THE DIFFERENCE OF "UNDERSTANDING" BETWEEN TRADITIONAL TEACHING AND EXPERIENTIAL

\begin{tabular}{|l|l|l|}
\hline Control content & Traditional teaching & Experience teaching \\
\hline Assessment standards & $\begin{array}{l}\text { Whether is able in their own way to } \\
\text { express the acquired knowledge }\end{array}$ & $\begin{array}{l}\text { Whether can make a clear judgment on the knowledge } \\
\text { learned and make a reasonable inference to make self- } \\
\text { answers, and have self-insights to solve complex } \\
\text { practical problems }\end{array}$ \\
\hline The teaching focus & $\begin{array}{l}\text { Limited to analysis and mastery of the } \\
\text { dogmatic concept }\end{array}$ & $\begin{array}{l}\text { Combine knowledge with practical learning with a multi- } \\
\text { angle understanding }\end{array}$ \\
\hline $\begin{array}{l}\text { The usefulness of students in } \\
\text { teaching }\end{array}$ & $\begin{array}{l}\text { Passively accept the arguments of } \\
\text { others }\end{array}$ & Take the initiative to build self-knowledge system \\
\hline $\begin{array}{l}\text { Acquired adaptive } \\
\text { anaracteristics } \\
\text { knowledge } \\
\text { formation }\end{array}$ & $\begin{array}{l}\text { The universalization of knowledge } \\
\text { isolation existing in only mind }\end{array}$ & $\begin{array}{l}\text { Personalized knowledge structure and the integration of } \\
\text { knowledge in the mind }\end{array}$ \\
\hline $\begin{array}{l}\text { Eventual realization of the } \\
\text { results }\end{array}$ & Coping exam & Flexibility in the use of the actual life \\
\hline
\end{tabular}

The comparative analysis of the paper selected mathematical statistics data, first set the total number of samples $\mathrm{y}$ as $\mathrm{k}$, and set vector set after the observational data for each sample, which is $\mathrm{m}$ q-element vector, which means that the number of the observed data vector is qm $[9,10]$.

$$
\begin{array}{ccccccc}
\text { Sample } & V & a & l & u & e & \bar{x} \\
1 & x_{11} & x_{12} & \cdot & x_{1 n} & \cdot & \frac{x_{1}}{x_{2}} \\
2 & x_{21} & x_{22} & \cdot & x_{2 n} & \cdot & \cdot \\
\cdot & \cdot & \cdot & \cdot & \cdot & \cdot & \cdot \\
\cdot & \cdot & \cdot & \cdot & \cdot & \cdot & \cdot \\
\cdot & \cdot & \cdot & \cdot & \cdot & \cdot & \cdot \\
g & x_{g 1} & x_{g 2} & \cdot & x_{g n} & \cdot & x_{g}
\end{array}
$$

Vector expressions of various observational data are as follows[11,12]:

$$
y_{q \times 1}=\left(\begin{array}{l}
y_{j i 1} \\
y_{j i 2} \\
\ldots \\
y_{j i q}
\end{array}\right)=\mu+\tau_{j}+f_{j i} \quad\left\{\begin{array}{l}
j=1,2, \ldots, k \\
i=1,2, \ldots, m
\end{array}\right.
$$

The decomposition model of the above expression can be expressed as[13,14]:

$$
\mathrm{y}_{\mathrm{ji}}=\overline{\mathrm{y}}+\left(\overline{\mathrm{y}}_{j}-\overline{\mathrm{y}}\right)+\mathrm{y}_{\mathrm{ji}}-y_{j}
$$

$\mathrm{y}_{\mathrm{ji}}$ is the observation data of the samples y. $\overline{\mathrm{y}}_{\text {is }}$ the average value and we use $\hat{\mu}_{\text {to represent it. }}$

$\bar{y}_{j}-\bar{y}$ is estimated values of treatment effect, indicating with $\hat{\tau}_{i}$.

$\mathrm{y}_{\mathrm{ji}}-y_{j}$ is residual values, represented by $\hat{e}_{i j}$. 


\section{Implementation analysis of experiential teaching methods in the ideological and political education}

First for colleges and universities to carry out ideological and political education courses we selected both as a research object, and divided into classes I and II classes. Class I is the major traditional education while experiential education is class II, the first two classes conducted a test of the ideological and political education course, and we record the results, and then we carry out the traditional education and experiential education, which were compared for the final results. Next are the colleges and universities to carry out ideological and political education syllabus requirements to develop a specific schedule of ideological and political education, as is shown in Table 2.

TABLE II. EXPERIENTIAL TEACHING CONTENT AND SCHEDULE OF IDEOLOGICAL AND POLITICAL EDUCATION

\begin{tabular}{|l|l|}
\hline Course content & Experiential teaching project \\
\hline Cherish current life to open up the new vision & Thanksgiving experience, to write to thank or essay competition \\
\hline Pursuit of lofty ideals, establish lofty beliefs & Multi-role experience, mimic the transposition performances \\
\hline To inherit patriotism, carry forward the national spirit & Eight Dos and Don'ts and experience speech competition \\
\hline Comprehend the true meaning of life, the value of to create life & Volunteer activities \\
\hline To strengthen ideological training exercise the moral quality & Cultural activities on campus organizations participation \\
\hline $\begin{array}{l}\text { Comply with social ethics of the initiative to maintain public } \\
\text { order }\end{array}$ & Environmental experience and visit \\
\hline
\end{tabular}

After we usedifferent teaching methods for I, II classes before the experiment and after respectively, the interest of the ideological and political education course survey data is in Table 3 and Figure 2.

TABLE III. II STUDENTS' INTEREST IN LEARNING THE IDEOLOGICAL AND POLITICAL EDUCATION COURSE SURVEY ANALYSIS (BEFORE AND AFTER EXPERIMENT)

\begin{tabular}{|l|l|l|l|l|l|l|}
\hline & \multicolumn{1}{|c|}{ Class } & \multicolumn{1}{c|}{ Very fond } & \multicolumn{1}{c|}{ Prefer } & General & Dislike & Total \\
\hline \multirow{2}{*}{ Before the experiment } & Class I & 5 & 8 & 20 & 15 & 48 \\
\cline { 2 - 8 } & Class II & 7 & 5 & 23 & 13 & 48 \\
\hline \multirow{2}{*}{ After the experiment } & Class I & 10 & 11 & 18 & 9 & 48 \\
\cline { 2 - 8 } & Class II & 22 & 21 & 4 & 1 & 48 \\
\hline
\end{tabular}

From Table 3, before the experiment, two classes of students' interest in learning the extent of the ideological and political lessons which is comparable to the general reach more than $50 \%$ and so do the proportion of students who do not like it.

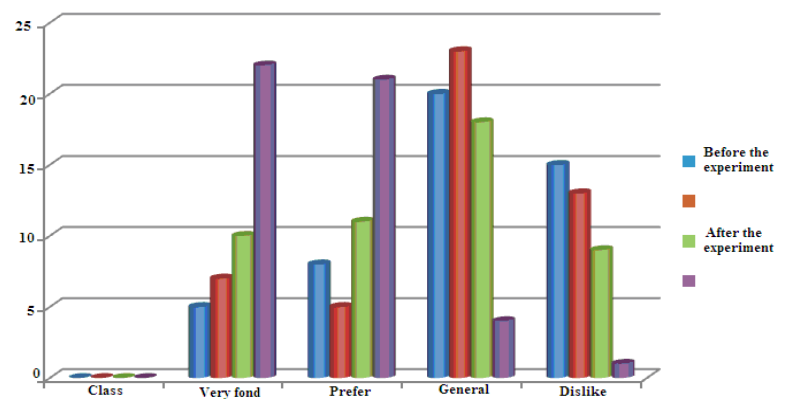

Figure 2. AB class students' interest in learning selected basketball course before the experiment survey results

In Figure 2, the experimental students from two classes of II their interest in learning for the ideological and political course has been greatly improved. There has also been a big difference. Students that are very fond of and like the ratio of the two classes I, II, are on the rise, but the rate of rise of the II class is much larger than I classes. The II classes' very fond is accounting for greater than $50 \%$.

TABLE IV. CLASS I, II STUDENTS' IDEOLOGICAL AND POLITICAL TEST RESULTS TABLE

\begin{tabular}{|l|l|l|}
\hline \multicolumn{1}{|c|}{ Grade } & \multicolumn{1}{c|}{ Class II } & \multicolumn{1}{c|}{ Class I } \\
\hline Outstanding & $48 \%$ & $21 \%$ \\
\hline Good & $31 \%$ & $30 \%$ \\
\hline Credit & $21 \%$ & $40 \%$ \\
\hline Fail & 0 & $9 \%$ \\
\hline
\end{tabular}


In Table 4, Class I and II students' ideological and political test results scores are significantly better than I, and this is precisely verify the positive role of experiential education for the students' ideological and political education to help improve students' ideological and political interest in teaching, while improving the results of the students' ideological and political course.

\section{Conclusion}

Traditional ideological and political education mode not only makes the students into the inherent way, but will also cause the passivity of ideas, which does not fit the actual situation. Truly effective ideological and political education need to be able to deeply rooted deep education. This experiential teaching method for the ideological and political education has played a significant role. For traditional ideological and political education, the teachers merely taken the traditional spoonfeeding way of teaching, not only does not mention the interest of the students in this course, it is unable to obtain the upgrade of the spiritual qualities, just to the courses can be obtained credits. The experiential teaching emphasis is on starting from the student body, to emphasize a people-oriented thinking. The experiential teaching not only makes students' thinking get excited and creation, but also creates a good classroom atmosphere, improving the efficiency of the ideological and political education. It is for the ideological quality and comprehensive development of the students. It is about the students' ideological and political education to the needs of the students, and also about the needs of the community. Students should enhance the quality of their own spiritual and self-development, and improve themselves in an important way, but also meet the social need for the comprehensive development of healthy personality qualities.

\section{References}

[1] Li Ying. Experience: a pedagogy discourse - Preliminary pedagogy experience areas [J]. Educational theory and practice, 2011 (12):83-86

[2] Xu Bin. Healthy growth of students in experiential teaching [J]. Modern Primary and Secondary Education,2009 (11):75-78.

[3] Ji Yuchao, Yang Xiangrong. The local colleges' experiential entrepreneurship education model building - Qingdao University as an example [J]. Schools Party building and ideological education ,2010 (35):37-39

[4] Wang Jixin. Thinking of the case teaching method - to the ideological and moral cultivation and legal basis "course as an example [J]. Shanxi Science and Technology,2012 (01):4-6.

[5] Zhu Aihong. On College Ideological and Political Teaching links to improve and optimize [J]. Waterway China (theory),2010 (07):102-103.

[6] Zhang Hua. Concept of experience curriculum theory - a holism courses (in) [J]. Educational theory and practice ,2011 (11):67-69.

[7] $\mathrm{Li} \mathrm{Li}$. Experiential teaching in ideological and moral teaching [J].Journal of Yanbian University,.2009 (03):25-27.

[8] Su Yujuan. Experiential teaching: characteristics, role and strategy - based analysis to improve students' innovative ability [J]. Shanxi Provincial Party School,2010 (03):44-47.

[9] Chen Antao. Experiential teaching model in the ideological and political theory courses School Party building and ideological education [J]. . Educational theory and practice ,2010 (26)

[10] Zhang Tiedao. Case studies on experiential teacher training methods -- Also on the promotion of certain principles of adult learning [J]. Educational research,2011 (05):54-56.

[11] Xin Jixiang. Experience teaching and research [M]. Hunan University Press, 2010:445-447.

[12] Wei Wenguang. Talking experiential teaching method in the teaching of the ideological and moral cultivation and legal basis [J]. Journal of Heihe University,2012 (02):56-57.

[13] Chen Lanping,. Xie Jiguang. Explore the implementation of experiential teaching in counseling psychology courses [J]. Journal of Weinan Normal University, 2010 (06):11-13.

[14] Jiang Xuefa. Experiential teaching in junior high school in the ideological and political course [J] Journal of Jingchu University of Technology,.2009 (05):31-33. 